\title{
Molecular Detection of Staphylococcal Enterotoxins and mecA Genes Products in Selected Food Samples Collected from Different Areas in Khartoum State
}

\author{
Mohammed Yahya Ahmed ${ }^{1 D},{ }^{1}$ Hashim Abdalbagi Ali, ${ }^{1}$ \\ Babbiker Mohammed Taher Gorish, ${ }^{2}$ Sara Omer Ali, ${ }^{1}$ Eman Saif Aldein Abdalrhim, ${ }^{1}$ \\ Mawada Hamza Mergani, ${ }^{1}$ Asmaa Abass Abd Elgadir, ${ }^{1}$ Somaya Khalid Mohammed, \\ Salma Omer Ahmed, ${ }^{1}$ Naglaa Alsaeid Musa, ${ }^{1}$ Alaa Saeed Ahmed, \\ Wafaa Mohammed Abdalla, ${ }^{1}$ Yousif Fadlallah Hamedelnil, ${ }^{1}$ Ahmed Ibrahim Hashim, ${ }^{1}$ \\ and Hisham N. Altayb ${ }^{1,3}$ \\ ${ }^{1}$ Department of Microbiology, Faculty of Medical Laboratory Science, Sudan University of Science and Technology, \\ Khartoum, Sudan \\ ${ }^{2}$ Department of Microbiology, Faculty of Medical Laboratory Science, Omdurman Islamic University, Omdurman, Sudan \\ ${ }^{3}$ Department of Biochemistry, Faculty of Sciences, King Abdulaziz University, Jeddah, Saudi Arabia
}

Correspondence should be addressed to Mohammed Yahya Ahmed; mohammedyhaya707@gmail.com

Received 5 February 2021; Accepted 10 March 2021; Published 20 March 2021

Academic Editor: Giuseppe Comi

Copyright ( $) 2021$ Mohammed Yahya Ahmed et al. This is an open access article distributed under the Creative Commons Attribution License, which permits unrestricted use, distribution, and reproduction in any medium, provided the original work is properly cited.

\begin{abstract}
Staphylococcal food poisoning is an intoxication that results from the consumption of improperly prepared or stored foods containing sufficient amounts of one or more preformed S. aureus enterotoxins. Nowadays, many researchers worldwide noted an emergence of resistant strains such as Staphylococci particularly for the antibiotic methicillin. Therefore, this study was aimed to determine the existence of Staphylococcus aureus and its enterotoxins, mecA genes, in selected food samples. A total of 400 selected food samples were collected from different areas in Khartoum State. The selected foods included cheese, meat products, fish, and raw milk. One hundred samples from each type of food were cultivated, and the resultant growth yielded 137 (34.25\%) S. aureus, 126 (31.5\%) bacteria other than S. aureus, and 137 (34.25\%) yielded no growth. Eighty-four of the 137 S. aureus isolates were randomly selected and tested for the presence of mecA and enterotoxin genes. The oxacillin sensitivity test showed that 15 (11\%) of 137 S. aureus isolates were oxacillin resistant. The PCR assay showed that the mecA gene was detected in 15 of 84 (17\%) S. aureus isolates. Simultaneously, only $2(2.385 \%)$ out of 84 S. aureus isolates showed an enterotoxin B gene product. There was a relatively moderate prevalence of methicillin-resistant Staphylococcus aureus with very low frequency of enterotoxin B gene in different kinds of selected food samples collected from Khartoum State. These findings elucidate the increased risk on public in Khartoum being affected by Staphylococcal food poisoning upon consumption of dairy or meat products prepared in unhygienic conditions that could lead to intoxication by Staphylococcus aureus enterotoxins.
\end{abstract}

\section{Background}

Foodborne diseases (FBD) remain as one of the greatest concerns in public health and food safety; they are caused by many pathogens that contaminate food and food products [1]. Many food sources may serve as a substrate for many microorganisms which are transmitted during harvesting, storage, food processing, and handling by multiple environmental sources such as water, soil, insects, or even by the handlers [2].

Staphylococcal food poisoning (SFP) is an intoxication that results from the consumption of improperly prepared or 
stored foods containing sufficient amounts of one or more preformed enterotoxins [3, 4]. A wide variety of foods support the growth of Staphylococcus aureus and are ideal for enterotoxin production including milk, meat, meat products, dairy products, and ready-to-eat food $[5,6]$.

Although Staphylococcus aureus may produce a large variety of enterotoxins, $95 \%$ of food poisoning outbreaks are caused by classical enterotoxins A, B, C, D, and E [7]. Since these toxic proteins are capable of tolerating high temperatures up to $100^{\circ} \mathrm{C}$ for several minutes, improperly cooked food contaminated with bacteria or its preformed toxins in sufficient amounts could lead to Staphylococcal food poisoning within a few hours characterized by symptoms including nausea, vomiting, and diarrhea [8]. Some strains of Staphylococcus aureus have the ability to resist heat and drying; hence, it can easily contaminate foods. This contamination might come from food handlers or from the environment where the bacteria multiply and release toxins in uncooked or inadequately cooked foods, especially if the foods are unrefrigerated [9]. The consumption of foods of animal origin contaminated with MRSA or MRSA preformed enterotoxins could lead to serious threats to the wellbeing of humans due to uncountable clinical implications [10].

Nonhygienic handling practices, working conditions, and improper storage and refrigeration can all increase the opportunity for food contamination. So, it is important to follow the standard practices in food handling such as hand washing, proper cooking, proper storage, and others to reduce or prevent food contamination [11, 12].

There is paucity of information in Sudan regarding the role Staphylococcus aureus in food poisoning and the presence of enterotoxins in mecA genes in common consumed foods in Khartoum State. Hence, this study was conducted to determine the prevalence of enterotoxins and mecA genes in foods commonly consumed in Khartoum State, Sudan.

\section{Methods}

2.1. Collection of Selected Food Samples. A total of 400 samples were collected from different areas in Khartoum State (Khartoum, Omdurman, East Nile, and Khartoum North), during 2018. The type of foods included cheese, meat products, fish, and raw milk. Each sample was aseptically collected, fifteen grams of cheese samples were collected from different retailers by using sterile container, meat samples were collected randomly from supermarkets and restaurants using disposable blades, a small piece of raw meat had been splitted and transferred to the lab in sterile containers, small pieces of fish inner tissues were collected by a sterile blade and placed in sterile plain containers, and milk samples were collected in sterile containers and stored in a refrigerator at $4^{\circ} \mathrm{C}$ in the microbiology laboratory until examined.

2.2. Isolation and Identification of Coagulase-Positive Staphylococcus Isolates. Meat, fish, and cheese samples were enriched in peptone water. The raw milk and the enriched peptone water samples were swabbed and inoculated in blood agar medium, mannitol salt agar medium, and MacConkey's agar medium and incubated aerobically at $37^{\circ} \mathrm{C}$ for $24-48 \mathrm{hrs}$. The presence of Staphylococcus aureus was confirmed based on colony morphology, Gram's reaction, and other biochemical tests including the catalase test, coagulase test, and DNase test.

2.3. Antimicrobial Susceptibility Testing of Coagulase-Positive Staphylococci. The antimicrobial susceptibility test was performed by the disk diffusion method using Mueller-Hinton agar plates (oxoid) according to [13], where 4 antimicrobial agents belonging to different classes were selected including ciprofloxacin $(5 \mu \mathrm{g})$, gentamicin $(10 \mu \mathrm{g})$, oxacillin $(5 \mu \mathrm{g})$, and vancomycin $(30 \mu \mathrm{g})$. The $S$. aureus ATCC 52923 control strain was used.

2.4. DNA Extraction. DNA was extracted by the simple boiling method, in which the extracted product was obtained from overnight isolates on nutrient agar. A loop full of bacterial colony was picked from an isolate and suspended in $300 \mu \mathrm{l}$ of sterile distilled water, and $10 \mu \mathrm{l}$ of proteinase $\mathrm{K}$ was added and incubated at $6^{\circ} \mathrm{C}$ for 60 minutes. Then, it was incubated at $100^{\circ} \mathrm{C}$ in a waterbath for 15 minutes, and the suspension was centrifuged at high speed $(10000 \mathrm{rpm}$ for $10 \mathrm{~min}$ ). The supernatant containing the genomic DNA was transferred into a fresh sterile Eppendorf tube and stored at $-20^{\circ} \mathrm{C}$ until to be used for PCR [14].

2.5. PCR Detection of $16 s$ rRNA Gene. All samples were confirmed as $S$. aureus by using specific housekeeping gene primer (16s) as shown in Table 1. Negative samples were excluded. The DNA amplifications were performed from a volume of $25 \mu \mathrm{L}$ of a mixture containing $2 \mu \mathrm{L}$ Maxime PCR Premix, $0.5 \mu \mathrm{L}$ of each primer, $2 \mu \mathrm{L}$ of template DNA, and $20 \mu \mathrm{L}$ of double distilled water. The amplification conditions included three steps: initial denaturation at $94^{\circ} \mathrm{C}$ for $5 \mathrm{~min}$; 35 successful cycles of denaturation at $94^{\circ} \mathrm{C}$ for $45 \mathrm{sec}$, annealing at $50^{\circ} \mathrm{C}$ for $45 \mathrm{sec}$, and extension at $72^{\circ} \mathrm{C}$ for $45 \mathrm{sec}$; and the final extension at $72^{\circ} \mathrm{C}$ for $7 \mathrm{~min}$ [12].

2.6. PCR Detection of Staphylococcal Enterotoxins Genes. Multiplex PCR amplification was performed using the CLASSIC K960 (UK) thermocycler. PCR amplification of Staphylococcal enterotoxins (SE) genes, namely, sea, seb, sec, sed, and see, was performed using the Maxime PCR PreMix kit (iNtRON, Korea) and specific primers listed in Table 2. The PCR assay was carried out in a total volume of $25 \mu \mathrm{L}$ of mixture containing $2 \mu \mathrm{L}$ Maxime PCR PreMix, $0.5 \mu \mathrm{L}$ of each of the toxic gene-specific primers $(5 \mu \mathrm{L})$, $2 \mu \mathrm{L}$ of template DNA, and $16 \mu \mathrm{L}$ of double distilled water. The amplification conditions included three steps: initial denaturation at $94^{\circ} \mathrm{C}$ for $5 \mathrm{~min}$; 35 successful cycles of denaturation at $94^{\circ} \mathrm{C}$ for $45 \mathrm{sec}$, annealing at $50^{\circ} \mathrm{C}$ for $45 \mathrm{sec}$, and extension at $72^{\circ} \mathrm{C}$ for $45 \mathrm{sec}$; and the final extension at $72^{\circ} \mathrm{C}$ for $7 \mathrm{~min}$ [12]. 
TAвLE 1: Antimicrobial sensitivity pattern of Staphylococcus aureus isolated from different food material samples.

\begin{tabular}{|c|c|c|c|c|c|}
\hline \multirow{2}{*}{ Isolates } & \multirow{2}{*}{ Pattern } & \multicolumn{4}{|c|}{ Antibiotics } \\
\hline & & Gentamicin $(10 \mathrm{mg})$ & Ciprofloxacin (5 mg) & Oxacillin (5 mg) & Vancomycin $(30 \mathrm{mg})$ \\
\hline \multirow{2}{*}{ Meat } & Sensitive & $26(86.7 \%)$ & $30(100 \%)$ & $28(93.4 \%)$ & $25(83.3 \%)$ \\
\hline & Resistant & $4(13.3 \%)$ & $0(0 \%)$ & $2(6.6 \%)$ & $5(16.7 \%)$ \\
\hline \multirow{2}{*}{ Cheese } & Sensitive & $20(100 \%)$ & $20(100 \%)$ & $19(95 \%)$ & $17(85 \%)$ \\
\hline & Resistant & $0(0 \%)$ & $0(0 \%)$ & $1(5 \%)$ & $3(15 \%)$ \\
\hline \multirow{2}{*}{ Fish } & Sensitive & $24(100 \%)$ & $100(100 \%)$ & $22(92 \%)$ & $22(92 \%)$ \\
\hline & Resistant & $0(0 \%)$ & $0(0 \%)$ & $2(8 \%)$ & $2(8 \%)$ \\
\hline \multirow{2}{*}{ Milk } & Sensitive & $55(87.3 \%)$ & $62(98.4 \%)$ & $53(84 \%)$ & $41(65 \%)$ \\
\hline & Resistant & $8(12.7 \%)$ & $1(1.6 \%)$ & $10(16 \%)$ & $22(35 \%)$ \\
\hline \multicolumn{2}{|c|}{ Total } & 137 & 137 & 137 & 137 \\
\hline
\end{tabular}

TABle 2: Primers used for detection of S. aureus housekeeping gene, enterotoxins, and mecA genes.

\begin{tabular}{lcc}
\hline Primer & Sequence 5'-3' & $\begin{array}{c}\text { Product } \\
\text { size (bp) }\end{array}$ \\
\hline Housekeeping gene primers & \\
Staph 756-F & AACTCTGTTATTAGGGAAGAACA & - \\
Staph 750-R & CCACCTTCCTCCGGTTTGTCACC & 756 \\
Enterotoxins genes primers & \\
SA-Ua-F & TGTATGTATGGAGGTGTAAC & - \\
SA-A-R & ATTAACCGAAGGTTCTGT & 270 \\
SA-B-R & ATAGTGACGAGTTAGGTA & 165 \\
ENT-C-R & AAGTACATTTTGTAAGTTCC & 102 \\
SA-D-R & TTCGGGAAAATCACCCTTAA & 303 \\
SA-E-R & GCCAAAGCTGTCTGAG & 213 \\
mecA gene primers & \\
MecA1-F & AACTCTGTTATTAGGGAAGAACA & - \\
MecA1-R & CCACCTTCCTCCGGTTTGTCACC & 310 \\
\hline
\end{tabular}

$\mathrm{Ua}$, universal; $\mathrm{f}$, forward; $r$, reverse.

2.7. PCR Detection of mecA Gene. Primers were used for the detection of mecA gene, as shown in Table 1. DNA amplification was performed using the Maxime PCR PreMix kit (iNtRON, Korea). The PCR assay was carried out in a total volume of $20 \mu \mathrm{L}$ of mixture containing $2 \mu \mathrm{L}$ Maxime PCR PreMix, $0.5 \mu \mathrm{L}$ of each of the gene-specific primers $(5 \mu \mathrm{L})$, $2 \mu \mathrm{L}$ of template DNA, and $13 \mu \mathrm{L}$ of double distilled water. The amplification conditions included three steps: initial denaturation at $94^{\circ} \mathrm{C}$ for $5 \mathrm{~min} ; 35$ successful cycles of denaturation at $94^{\circ} \mathrm{C}$ for $45 \mathrm{sec}$, annealing at $52^{\circ} \mathrm{C}$ for $45 \mathrm{sec}$, and extension at $72^{\circ} \mathrm{C}$ for $45 \mathrm{sec}$; and the final extension at $72^{\circ} \mathrm{C}$ for $7 \mathrm{~min}$.

2.8. Quality Control. All samples were aseptically collected and analyzed; positive control which was a well-known enterotoxin and mecA gene producing Staphylococcus aureus and negative control which was sterile distilled water were included during PCR running.

\section{Results}

3.1. Prevalence of S. aureus Isolates in Food Samples. The presence of S. aureus was observed in 137 (34.25\%) of the 400 food samples collected from different areas in Khartoum State.
However, 126 (31.5\%) of the 400 samples were identified as bacteria other than S. aureus, and 137 (34.25\%) samples did not yield any growth (Table 3 ). All isolated $S$. aureus were confirmed by detection of the $16 \mathrm{~S}$ rRNA housekeeping gene product which corresponds to $756 \mathrm{bp}$ band size (Figure 1).

3.2. Detection of mecA and Enterotoxins Genes among S. aureus Isolates. The 84 different $S$. aureus isolates were randomly selected from a total of 137 S. aureus isolates. The selected isolates were further examined for the presence mecA and enterotoxin genes using specific primer in a conventional PCR assay. The mecA gene was detected in 15 (17\%) S. aureus isolates (in samples number 6, 13, 55, 63, and 81 of meat; samples number 2, 11, 47, and 72 for cheese; in samples number $19,28,34$, and 49 of milk; and in samples number 9 and 38 of fish (Table 4) (Figures 1 and $2)$ ). However, only $2(2.385 \%)$ of $84 \mathrm{~S}$. aureus isolates showed an enterotoxin B gene product (both isolates were from cheese samples and the samples ID were 16 and 31), while the rest of 82 isolates were negative. All isolates were negative for other enterotoxins gene (other than seb gene) (Table 4) (Figure 3).

3.3. Meat Isolates' Antimicrobial Susceptibility Characteristics. Presence of S. aureus was observed in 30 $(30 \%)$ of the 100 milk samples (Table 5), of which 11 $(36.7 \%)$ isolates were detected in raw beef and $19(63.3 \%)$ were identified in restaurants meat. However, $20(20 \%)$ samples showed the growth of bacteria other than S. aureus, and $50(50 \%)$ samples showed no growth. All tested meat $S$. aureus isolates were susceptible to ciprofloxacin. The resistant rates of meat $S$. aureus isolates to gentamicin was 4 $(13.3 \%)$, and it was higher than that identified to the antibiotics oxacillin and vancomycin with $2(6.6 \%)$ and 5 $(16.7 \%)$, respectively (Table 1 ). The PCR assay for enterotoxin gene products showed that none of the meat $S$. aureus isolates produced enterotoxins genes products (Figure 3).

3.4. Cheese Isolates' Antimicrobial Susceptibility Characteristics. The examination of 100 cheese samples collected from different areas in Khartoum State revealed that the occurrence of S. aureus isolate was 20 (20\%), while 
TABLE 3: Distribution of bacteria isolated from selected food samples purchased from retailers in Khartoum State.

\begin{tabular}{lcc}
\hline Isolate & Number & Percentage (\%) \\
\hline Staphylococcus aureus & 137 & 34.25 \\
Others bacteria & 126 & 31.5 \\
No growth & 137 & 34.25 \\
Total & 400 & 100 \\
\hline
\end{tabular}

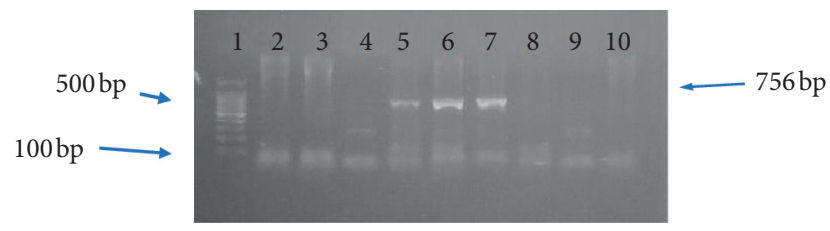

FIgURE 1: PCR amplification of $16 \mathrm{~S}$ rRNA gene of S. aureus on $2 \%$ agarose gel electrophoresis. Lane 1 DNA ladder, MW 100-1500 bp fragments. Lanes 5, 6, and 7 show a typical band size of $756 \mathrm{bp}$ corresponding to $16 \mathrm{~S}$ rRNA of positive control isolates (isolates IDs 13,55 , and 63 , respectively). Lanes $2,3,4$, and 8 are the negative samples.

TABLE 4: Distribution of mecA and enterotoxin genes among Staphylococcus aureus isolates.

\begin{tabular}{lccc}
\hline Type of gene detected & Positive & Negative & Total \\
\hline mecA gene & $15(17.9 \%)$ & $69(82.1 \%)$ & $84(100 \%)$ \\
Enterotoxin B gene & $2(2.38 \%)$ & $82(97,62 \%)$ & $84(100 \%)$ \\
Other enterotoxin genes & $0(0 \%)$ & $84(100 \%)$ & $84(100 \%)$ \\
\hline
\end{tabular}

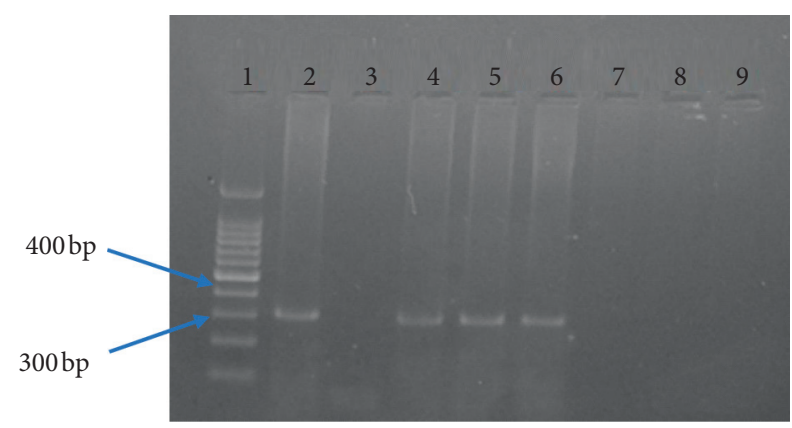

FIGURE 2: PCR amplification of mecA gene of S. aureus on $2 \%$ agarose gel electrophoresis. Lane 1 DNA ladder, MW 100-1500 bp fragments. Lanes 2, 4, 5, and 6 show a typical band size of $310 \mathrm{bp}$ corresponding to mecA gene products of $S$. aureus isolated from samples number 13, 55, 63, and 81. Lanes 3, 7, 8, and 9 are the negative samples.

bacteria other than $S$. aureus represented $4 \%$. However, none of the rest $76(76 \%)$ showed any growth on the agar plate surface (Table 5). We found that all isolates were susceptible to both gentamicin and ciprofloxacin antibiotics. However, vancomycin showed growth-inhibition zones with 17 (85\%) isolates out of 20 positive samples. Only one (5\%) cheese $S$. aureus isolate was resistant to oxacillin (Table 1). Enterotoxin gene B (seb) was detected only in $2(10 \%)$ of cheese isolates (samples 16 and 31), while none of other types of enterotoxin genes products was detected among these isolates (Figure 3).

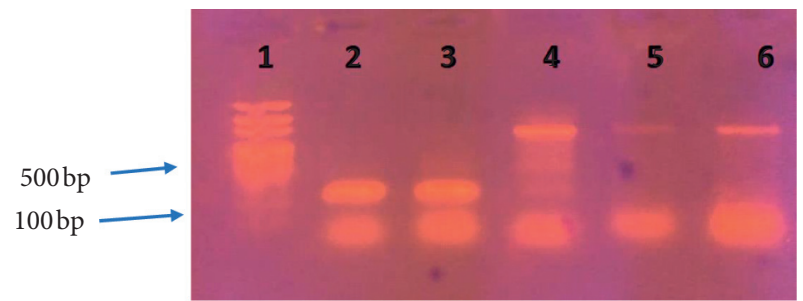

FIgURE 3: Agarose gel electrophoresis for PCR product of enterotoxin B gene (165 bp) and 16s rRNA (756bp). Lane 1, DNA ladder $50 \mathrm{bp}$. Lane 2 shows a typical band of the positive control $S$. aureus enterotoxin B seb gene. Lane 3 shows a positive enterotoxin B gene product of $S$. aureus isolated from cheese samples (sample 16). Bands 4,5 , and 6 show a positive sample for 16s rRNA gene (isolates 16, 17, and 31).

3.5. Antimicrobial Profile for Fish S. aureus Isolates. In this study, a total of 100 fish samples (50 salted fish and 50 raw fish) were analyzed for the presence of bacterial pathogens. The study revealed that 24/100 (24\%) of the fish samples had S. aureus contamination (Table 5). Antibiotic susceptibility of $S$. aureus was tested using the agar disc diffusion method. The results have shown that all fish originated $S$. aureus isolates were susceptible to both ciprofloxacin and gentamicin antibiotics. In contrast, the resistance rate was only $8 \%$ to both vancomycin and oxacillin antibiotics (Table 1). No enterotoxin gene product was detected during the gel electrophoresis procedure which was applied after successful cycles of conventional PCR (Figure 3).

3.6. Antimicrobial Profile for Milk S. aureus Isolates. Out of 100 milk samples collected from different areas in Khartoum State, 63 (63\%) were identified as S. aureus, 26 (26\%) were identified as bacteria others than S. aureus, and $11(11 \%)$ showed no growth (Table 5). The antimicrobial susceptibility test was performed to all $S$. aureus isolates, and the result showed that the highest susceptibility rate was recorded to ciprofloxacin and gentamicin with a percentage of $98.4 \%$ (62/63 isolates) and $87.3 \%$ (55/63 isolates), respectively, followed by oxacillin with a percentage of $84 \%(53 / 63)$. However, the least potent antibiotic was vancomycin with a percentage of $65 \%(41 / 63)$ (Table 1$)$. The enterotoxin genes results reveal that no $S$. aureus isolate produces such genes (Figure 3).

\section{Discussion}

In this study, the prevalence of $S$. aureus and MRSA and enterotoxin gene products were investigated in various food samples collected from Khartoum State markets (400 samples of milk, cheese, fish, and meat). Identification of the bacteria isolated from the selected foods through conventional methods yielded a total of 137 (34.3\%) S. aureus isolates. Similar reports on foods contaminated with $S$. aureus from Italy and India revealed much lower percentage yielding $17.1 \%$ [15] and $12.01 \%$ [16], respectively. The previous studies conducted to detect $S$. aureus in various foods revealed that the contamination levels with $S$. aureus 
TABLE 5: Distribution of Staphylococcus aureus isolates according to the type of food samples.

\begin{tabular}{lcccc}
\hline Sample & S. aureus isolates & Other bacteria isolates & No growth & Total \\
\hline Meat & $30(30 \%)$ & $20(20 \%)$ & $50(50 \%)$ & $100(100 \%)$ \\
Cheese & $20(20 \%)$ & $4(4 \%)$ & $76(76 \%)$ & $100(100 \%)$ \\
Fish & $24(24 \%)$ & $76(76 \%)$ & $0(0 \%)$ & $100(100 \%)$ \\
Milk & $63(63 \%)$ & $26(26 \%)$ & $11 \%)$ & $11 \%(100 \%)$ \\
Total & 137 & 126 & 137 & 400 \\
\hline
\end{tabular}

reported were lower than those obtained in this study. On the other hand, a study in Greece reported $47.8 \%$ of northcentral and northeastern Greece foods, which have a much higher contamination level compared to those reported in this study [3]. Those great discrepancies between our finding and other studies results may be due to variation in foods, habits, cooking behaviors, and food keeping hygiene in addition to environmental factors such as the weather temperature and moist which significantly affect bacterial growth in food materials.

In this study, resistance gene (mecA) of $S$. aureus responsible for resistance to $\beta$-lactam antimicrobials was detected by using PCR, and we found that 15 (17\%) S. aureus isolates were positive for the mecA gene while $69(83 \%)$ were negative. Comparing our finding to previous studies results, we realized that most of the previous studies results showed a significantly higher prevalence than our finding, for example, in a study performed by Khayri in Makkah city, about $44.4 \%$ of his $S$. aureus isolates were positive for mecA gene [4]. Similarly, Papadopoulos and his colleagues found that $81.3 \%$ of their S. aureus isolates were positive for the mecA gene [3]. This variation could be due to the difference in the antibiotic protocol applied by doctors for their patients in different countries or due to the extensive usage of methicillin antibiotics by their communities or by doctors during treatment prescription in these countries that eventually lead to a high prevalence rate of MRSA. On the contrary, the results reported in this study are higher than those reported by Aydin et al. [5] where the mecA gene prevalence was only $11.4 \%$. Low rates of mecA gene were also reported in Egypt, Brazil, and China where the prevalence of mecA gene was $5.1 \%, 9 \%$, and $7.9 \%$, respectively [6-8]. The variation between the results may be due to variation of samples sources and the use of different molecular techniques in different countries for the detection of mecA gene product.

In this study, one hundred raw meat samples were obtained from different supermarkets and restaurants in Khartoum State. These samples are examined for the presence of S. aureus. Thirty (30\%) samples were found to be contaminated with $S$. aureus. These findings highlight the high potential risk for consumers of meat and dairy products especially in the absence of strict hygienic and preventive measures to avoid Staphylococcus aureus enterotoxins (SEs) production in foods. In other comparative studies, similar results were reported from the USA where the prevalence of S. aureus in meat samples was $29.0 \%$ [17]. Much lower results were reported in South Africa, who reported that S. aureus was $26.5 \%$ [18]. Also, our result is lower than that obtained by Das and Mazumder in India who reported that out of 65 samples, S. aureus incidence was in $46.1 \%$ [19]. In our study, none of the meat $S$. aureus isolates was resistant to ciprofloxacin and $13.3 \%$ was resistant to gentamicin. In disagreement with our result, Das and Mazumder in India found that $16.66 \%$ of S. aureus meat isolates were resistant to ciprofloxacin [19] and $\mathrm{Pu}$ et al. in Louisiana found that $13.0 \%$ was resistant to ciprofloxacin. Also, in contrast to our findings, Pu et al. in Louisiana found that 3.0\% was resistant to gentamicin [20]. Vancomycin-resistant Staphylococcus aureus (VRSA) is a type of antibiotic-resistant $S$. aureus which have developed resistance and can no longer be treated with vancomycin. This study showed that $16.6 \%$ of the meat isolates were resistant to vancomycin, which suggests that the contamination may be coming from VRSA carrier's food handlers and processors; however, Das and Mazumder found that $3.33 \%$ of the isolates were resistant to vancomycin (VRSA) which is low compared with our findings [19]. Methicillin-resistant S. aureus (MRSA) strains have acquired a gene that makes them resistant to nearly all beta-lactam antibiotics; animal-adapted MRSA strains also exist. Although it is in small percentage, it has clinical importance and may cause serious problems to immunocompromised individuals as well as healthy ones (carriers). In this study, $6.6 \%$ of meat isolates were resistant to oxacillin; this finding was high compared to the results of van Loo et al. who found that $2.5 \%$ of $S$. aureus meat isolates were resistant to oxacillin [21] and low compared to the results of Das and Mazumder who found that $23.3 \%$ of $S$. aureus isolates were resistant to oxacillin [19].

Investigations through PCR technique on enterotoxin genes in this study showed the absence of enterotoxin genes in meat $S$. aureus isolates. A similar study in Denmark demonstrated the presence of enterotoxin genes in only $0.2 \%$ of the isolates [22]. On the other hand, a report from China demonstrated the prevalence of $46.0 \%$ enterotoxin gene [23], and Bergdoll found that the percentage of enterotoxigenic strains of S. aureus is estimated to be around 25\% [24]. Moreover, most of $S$. aureus food isolates are not SEs producers; thus, a considerable research effort is still required for a better understanding of the interactions between S. aureus and the food matrix and of the mechanism of SEs production in foods stuffs [25]. The data obtained in this study probably underestimated the enterotoxigenic properties of the analyzed strains, since the possible presence of newly described SEs was not considered and the sample size was too small to represent $S$. aureus-contaminated meat effectively. However, there is always the possibility of mutation at the level of the corresponding gene, leading to the absence of its detection. Therefore, a positive PCR shows the presence of the enterotoxin genes, but a negative PCR does not point to the absence of the corresponding operon 
because there are many types of enterotoxin genes and we determine only one type [25].

In this study, one hundred white cheese samples collected from different retailers in Khartoum State to detect the rate of $S$. aureus contamination in cheese sample in this study is higher than that reported in Iran and Japan where the reported contamination rates were $16 \%$ and $13.3 \%$, respectively $[26,27]$ and lower than that reported in Turkey which was $37.5 \%$ [28]. However, the results in this study disagree with a previous report in Khartoum State where no Staphylococcus aureus was found on white cheese [29]. This may be due to variation in sample sources where the cheese was manufactured, the retailers where cheese samples were purchased from, the sampling area, season, and environment; all these factors might affect the rate of contamination with microorganisms. The rate of sensitivity of cheese $S$. aureus isolates to gentamicin and ciprofloxacin was 100\%; these findings oppose those reported in the USA, where 75\% of $S$. aureus isolates were resistant to gentamicin [30] and in Iraq where $25 \%$ of $S$. aureus isolates were resistant to ciprofloxacin [31]. The resistance of cheese $S$. aureus to oxacillin in this study was $5 \%$, which was lower than that reported in Iraq which was 20\% [32]. The sensitivity to vancomycin was $85 \%$ which is lower than that reported in Switzerland which was $100 \%$ [33].

The molecular detection of Staphylococcus aureus enterotoxins $(\mathrm{A}, \mathrm{B}, \mathrm{C}, \mathrm{D}$, and $\mathrm{E})$ genes among cheese isolates resulted in the detection of seb gene in $10 \%$ of the 20 isolates that was lower than the results obtained by Salheen in Sudan who reported that $20 \%$ of seb gene was detected in cheese samples [34]. The variation between results could be due to several factors such as sample source, geographical origin, the sensitivity of identification methods, and sample size which can affect the outcomes.

In this study, 108 fish samples were examined. The contamination rate of fish samples in this study was very low (22\%) when compared with a previous report in Khartoum State (72\%) [35], Egypt (93\%) [11], and India (100\%) [36] and relatively lower than that reported in Spain (27\%) [37]. Antimicrobial susceptibility results for fish $S$. aureus isolates showed $100 \%$ sensitivity to ciprofloxacin, which was in agreement with reports in Egypt [11] and Turkey [38] and very close to a study and also nearly similar to reports in Portugal (98\%) [39]. However, lower result in India was 48.5\% [40] and in Egypt was 57\% [41]. Gentamicin also showed an efficacy rate of $100 \%$ among all S. aureus isolates, which is similar to reports from Egypt [41], Turkey [38], and that of Vázquez-sánchez et al. in Spain [37] and slightly similar to results reported in Egypt (97\%) [11] and in Portugal (92\%) [39]. In this study, S. aureus isolated from fish samples showed a sensitivity rate of $92 \%$ to vancomycin, which is similar to those reported in Egypt (91\%) [11] and Portugal (90\%) [39], respectively. Another study in Egypt reported a higher result (100\%) [41], while other studies in Turkey reported much lower sensitivity to vancomycin, which was $83 \%$ and $78 \%$, respectively $[38,42]$. The oxacillin showed $92 \%$ potency against fish $S$. aureus isolates which was higher than that reported in Portugal (62\%) [39], while it was relatively lower than those reported in Spain and Turkey where both reported $100 \%[37,38]$. The variation between these results could be due to contribution of several factors such as source of samples, geographical origin, sensitivity of identification methods, and sample size which can affect the outcomes.

The molecular detection of the enterotoxin's genes among fish S. aureus isolates gave no band for all genes meaning that none of the all isolates possesses such gene in their genetic material; this finding agreed with those reported in Turkey and the USA $[38,43]$, where no enterotoxins B, C, and E genes were found in their food S. aureus isolates. However, a study in Tanzania reported that enterotoxins $\mathrm{B}$ and $\mathrm{C}$ genes were detected in $0.3 \%$ with the absence of enterotoxin A gene [44], while a study from Turkey reported enterotoxins A and D genes in 10.5\% of their samples [38]. Variation among research studies' results and our findings could be due to several factors such as samples source, geographical origin, the sensitivity of identification methods, and sample size which can affect the outcomes.

In this study, S. aureus was isolated in $63 \%$ of raw milk samples, which is relatively close to that reported in Brazil (68\%) [45] and Malaysia (60\%) [46]. However, this finding was lower than those reported in Turkey (75\%) [47] and Egypt (82\%) [48]. The prevalence of this study is higher than those reported in two different studies in Iraq with prevalence of $53.33 \%$ and $43.5 \%$, respectively $[49,50]$. Moreover, the prevalence of $S$. aureus in this study is too high compared to reports from Sudan and Egypt where the levels were 30\% and $24.8 \%$, respectively $[51,52]$. S. aureus isolated from milk samples in this study were highly sensitive to ciprofloxacin (98.4\%), which is close to a report from a study in Bangladesh (93.3\%) [53]. However, relatively lower susceptibility levels were reported in India and Bangladesh where the rate was $80 \%$ and $83.3 \%$, respectively $[54,55]$. The sensitivity to gentamicin in this study (87\%) is lower than that reported in Ethiopia (90\%) [55, 56] and (100\%) [57] and higher compared to another report in Sudan which was 47.6\% [51].

While slightly similar to results obtained by Beyene in Ethiopia, Thaker et al. in India reported that $90 \%$ of S. aureus isolates were sensitive to gentamicin $[55,56]$. Reports from other researchers indicated a higher level of susceptibility rate to gentamicin, for instance, Abraha et al. in Ethiopia reported that $100 \%$ of milk $S$. aureus isolates are susceptible to gentamicin [57]. In this study, the vancomycin susceptibility test was determined for all milk-originated S. aureus, and the result showed that $65 \%$ of the S. aureus isolates were susceptible to vancomycin; this finding was completely close to findings reported by Idbeis, in Basrha in Iraqe, and ALMarsomy and Bendahou et al., in North Morocco, who mentioned that $S$. aureus isolated from raw milk and milk products showed sensitivity to vancomycin (100\%) [58-60]. On the contrary, studies from Ethiopia and Iraq reported $100 \%$ resistance to vancomycin $[57,61]$. The sensitivity to oxacillin (84\%) in this study is higher than that reported in India (70\%) [55] and lower than that reported in Bangladesh (100\%) [54]. All milk S. aureus isolates tested for the presence of enterotoxins genes yielded negative results. Similar findings were reported in Hungary [62]. The 
variations between results reported in this study and other reports could be attributed to several factors such as samples source, geographical origin, sensitivity of identification methods, and sample size which can affect the outcomes.

\section{Conclusion}

There was a relatively moderate prevalence of methicillinresistant Staphylococcus aureus with very low frequency of enterotoxin B gene in different kinds of selected food samples collected from Khartoum State. These findings elucidate the increased risk on public in Khartoum being affected by Staphylococcal food poisoning upon consumption of dairy or meat products prepared in unhygienic conditions that could lead to intoxication by Staphylococcus aureus enterotoxins.

\section{Data Availability}

The datasets analyzed during the current study are available from the corresponding author upon request.

\section{Disclosure}

The authors address that this article is presented as preprint in BMC Microbiology Journal.

\section{Conflicts of Interest}

The authors declare that they have no conflicts of interest.

\section{Acknowledgments}

The authors gratefully acknowledge the great effort of microbiology lab staff in Sudan University of Science and Technology. The authors also express their thanks and appreciation to all salesman in all markets who provided them the samples to achieve this research.

\section{References}

[1] E. E. Abd Elsalam, "Rapid method for detection of Staphylococcus aureus enterotoxins in food," B.V.Sc Thesis, Cairo University, Giza, Egypt, 2008.

[2] C. O. Ubiebi, "Isolation and identification of bacterial isolates from poultry and fish feeds sold in Abraka, Delta state, Nigeria," Journal of Industrial Technology, vol. 2, no. 1, pp. 14-20, 2017.

[3] P. Niveditha, R. Shylaja, M. Radhika, S. Murali, and B. Harshvardhan, "A novel mPCR for the detection of prominent toxins in MRSA strains of $S$. aureus recovered from diverse sources," International Journal of Scientific Research in Biological Sciences, vol. 2, no. 4, pp. 1-3, 2014.

[4] J. Schelin, N. Wallin-Carlquist, M. Thorup Cohn, R. Lindqvist, G. C. Barker, and P. Rådström, "The formation of Staphylococcus aureus enterotoxin in food environments and advances in risk assessment," Virulence, vol. 2, no. 6, pp. 580-592, 2011.

[5] A. Aydin, M. Sudagidan, and K. Muratoglu, "Prevalence of staphylococcal enterotoxins, toxin genes and genetic-relatedness of foodborne Staphylococcus aureus strains isolated in the Marmara Region of Turkey," International Journal of Food Microbiology, vol. 148, no. 2, pp. 99-106, 2011.

[6] C. Techer, M. Salmain, O. Tranquet et al., "Detection and quantification of staphylococcal enterotoxin A in foods with specific and sensitive polyclonal antibodies," Food Control, vol. 32, no. 1, pp. 255-261, 2013.

[7] C. Letertre, S. Perelle, F. Dilasser, and P. Fach, "Identification of a new putative enterotoxin SEU encoded by the egc cluster of Staphylococcus aureus," Journal of Applied Microbiology, vol. 95, no. 1, pp. 38-43, 2003.

[8] K. C. Carroll, J. Butel, and S. Morse, Jawetz Melnick \& Adelberg Medical Microbiologypp. 203-208, Mc Graw Hill Professional, New York, NY, USA, 27th edition, 2012.

[9] J. G. Black, Microbiology Principles and Explorationspp. 684-685, John Wiley and Sons, Hoboken, NJ, USA, 7th edition, 2008.

[10] S. Monecke, G. Coombs, A. C. Shore et al., "A field guide to pandemic, epidemic and sporadic clones of methicillin-resistant Staphylococcus aureus," PLoS One, vol. 6, no. 4, p. e17936, 2011.

[11] N. A. Ezzeldeen, H. A. Mansour, and A. A. Ahmed, "Phenotypic and molecular identification of Staphylococcus aureus isolated from some Egyptian salted fish," World Applied Science Journal, vol. 15, no. 12, pp. 1703-1712, 2015.

[12] L. H. Mahmoud, Molecular detection of Staphylococcus aureus toxin genes isolated from different clinical samples in Khartoum state, Ph.D. Thesis, Khartoum, Sudan.

[13] Clinical and Laboratory Standards Institute, Performance Standards for Antimicrobial Susceptibility Testing; TwentyFirst Informational Supplement. M100-S21, Clinical and Laboratory Standards Institute, Wayne, PA, USA, 2011.

[14] F. Compain, A. Babosan, S. Brisse et al., "Multiplex PCR for detection of seven virulence factors and $\mathrm{K} 1 / \mathrm{K} 2$ capsular serotypes of Klebsiella pneumoniae," Journal of Clinical Microbiology, vol. 52, no. 12, pp. 4377-4380, 2014.

[15] A. Traversa, G. R. Gariano, S. Gallina et al., "Methicillin resistance in Staphylococcus aureus strains isolated from food and wild animal carcasses in Italy," Food Microbiology, vol. 52, pp. 154-158, 2015.

[16] M. Sivakumar, Z. B. Dubal, A. Kumar et al., "Virulent methicillin resistant Staphylococcus aureus (MRSA) in street vended foods," Journal of Food Science and Technology, vol. 56, no. 3, pp. 1116-1126, 2019.

[17] A. Kelman, Y.-A. Soong, N. Dupuy et al., "Antimicrobial susceptibility of Staphylococcus aureus from retail ground meats," Journal of Food Protection, vol. 74, no. 10, pp. 1625-1629, 2011.

[18] T. Ramatla, N. Mphuthi, K. Gofaone, M. O. Taioe, O. M. M. Thekisoe, and M. Syakalima, "Identification of rodent species that infest poultry houses in Mafikeng, north west province, South Africa," International Journal of Zoology, vol. 2019, Article ID 1280578, 8 pages, 2019.

[19] P. Das and P. B. Mazumder, "Prevalence of Staphylococcus in raw meat samples in Southern Assam, India," Journal of Agriculture and Veterinary Science, vol. 9, no. 1, pp. 23-29, 2016.

[20] S. Pu, F. Wang, and B. Ge, "Characterization of toxin genes and antimicrobial susceptibility of Staphylococcus aureus isolates from louisiana retail meats," Foodborne Pathogens and Disease, vol. 8, no. 2, pp. 299-306, 2011.

[21] I. H. M. van Loo, B. M. W. Diederen, P. H. M. Savelkoul et al., "Methicillin-resistant Staphylococcus aureus in meat products, the Netherlands," Emerging Infectious Diseases, vol. 13, no. 11, pp. 1753-1755, 2007. 
[22] H. D. Larsen, A. Huda, N. H. R. Eriksen, and N. E. Jensen, "Differences between danish bovine and human Staphylococcus aureus isolates in possession of superantigens," Veterinary Microbiology, vol. 76, no. 2, pp. 153-162, 2000.

[23] S. Li, P. Wang, J. Zhao et al., "Characterization of toxin genes and antimicrobial susceptibility of Staphylococcus aureus from retail raw chicken meat," Journal of Food Protection, vol. 81, no. 4, pp. 528-533, 2018.

[24] M. S. Bergdoll, "Staphylococcus aureus," in Food Borne Bacterial Pathogens, M. Doyle, Ed., pp. 463-523, CRC Press, New York, NY, USA, 1989.

[25] Y. Le Loir, F. Baron, and M. Gautier, "Staphylococcus aureus and food poisoning," Genetics and Molecular Research, vol. 31, no. 1, pp. 63-76, 2003.

[26] D. Shanehbandi, B. Baradaran, S. Sadigh-Eteghad, and H. Zarredar, "Occurrence of methicillin resistant and enterotoxigenic Staphylococcus aureus in traditional cheeses in the north west of Iran," International Scholarly Research Notices, vol. 2014, Article ID 129580, 5 pages, 2014.

[27] K. Katsuda, E. Hata, H. Kobayashi et al., "Molecular typing of Staphylococcus aureus isolated from bovine mastitic milk on the basis of toxin genes and coagulase gene polymorphisms," Veterinary Microbiology, vol. 105, no. 3-4, pp. 301-305, 2005.

[28] A. Gucukoglu, T. O. Kevenk, T. Uyanik, O. Cadirci, G. Terzi, and M. Alisarli, "Detection of enterotoxigenic Staphylococcus aureus in raw milk and dairy products by multiplex PCR," Journal of Food Science, vol. 77, no. 11, pp. M620-M623, 2012.

[29] T. A. Mohamed, A. E. Kalid, and A. M. Saaclaki, "Isolation of Staphylococcus aureus from some semi preserved Sudanese food," Research Journal of Microbiology, vol. 9, no. 5, pp. 246-250, 2014.

[30] J. C. Seguin, R. D. Walker, J. P. Caron et al., "Methicillinresistant Staphylococcus aureus outbreak in a veterinary teaching hospital: potential human-to-animal transmission," Journal of Clinical Microbiology, vol. 37, no. 5, pp. 1459-1463, 1999.

[31] N. N. Jaber, "Isolation and biotyping of Staphylococcus aureus from white cheese in Basrah local markets," Basrah Journal of Veterinary Research, vol. 10, no. 2, 2011.

[32] A. H. Alshammary and M. H. Galfoori, "Detection of methicillin or multidrug resistant Staphylococcus aureus [MRSA] in locally produced raw milk and soft cheese in Baihadad markets Iraq," Journal of Veterinary Medicine, vol. 37, no. 2, pp. 226-231, 2013.

[33] E. Gentilini, G. Denamiel, P. Llorente, S. Godaly, M. Rebuelto, and O. DeGregorio, "Antimicrobial susceptibility of Staphylococcus aureus isolated from bovine mastitis in Argentina," Journal of Dairy Science, vol. 83, no. 6, pp. 1224-1227, 2000.

[34] E. M. Salheen, "Molecular detection of Staphylococcus aureus enterotoxin B in milk and milk product using PCR," M.Sc. Thesis, Sudan University of Science and Technology, Khartoum, Sudan, 2016.

[35] T. A. Mohammed, A. E. Khalid, and A. M. Saadabi, "PCR detection of staphylococcal enterotoxin A and B genes in Staphylococcus aureus isolated from salted fermented fish," Microbiology Journal, vol. 4, no. 2, pp. 51-56, 2014.

[36] S. Geetha, R. V. Govinda, K. N. Mudula, R. N. Ram, and B. K. Ramesh, "Some aspects of biochemical and microbial analysis of sundry fish Trichurus Linnaeus, 1758, from the east coast of Visakhapantam," International Journal of Advanced Biotechnology Research, vol. 4, no. 4, pp. 462-465, 2014.

[37] D. Vázquez-Sánchez, M. López-Cabo, P. Saá-Ibusquiza, and J. J. Rodríguez-Herrera, "Incidence and characterization of Staphylococcus aureus in fishery products marketed in Galicia
(Northwest Spain)," International Journal of Food Microbiology, vol. 157, no. 2, pp. 286-296, 2012.

[38] S. Arslan and F. Özdemir, "Molecular characterization and detection of enterotoxins, methicillin resistance genes and antimicrobial resistance of Staphylococcus aureus from fish and ground beef," Polish Journal of Veterinary Sciences, vol. 20, no. 1, pp. 85-94, 2017.

[39] V. Pereira, C. Lopes, A. Castro, J. Silva, P. Gibbs, and P. Teixeira, "Characterization for enterotoxin production, virulence factors, and antibiotic susceptibility of Staphylococcus aureus isolates from various foods in Portugal," Food Microbiology, vol. 26, no. 3, pp. 278-282, 2009.

[40] B. C. Parmar, M. Pal, and A. J. Dhami, "In vitro antimicrobial drug susceptibility pattern of Staphylococcus aureus strain," Indian Journal of Field Veterinarians, vol. 2, no. 1, pp. 46-48, 2006.

[41] S. I. Afifi and H. A. Al-Newery, "Bacteriological studies on some virulence factors of Staphylococcus aureus isolated from chicken and Nile tilapia," Journal of Chemistry and Environmental Health, vol. 3, no. 1, pp. 20-36, 2017.

[42] K. Guven, M. B. Mutlu, A. Gulbandilar, and P. Cakir, "Occurrence and characterization of Staphylococcus aureus isolated from meat and dairy products consumed in Turkey," Journal of Food Safety, vol. 30, no. 1, pp. 196-212, 2010.

[43] S. Pu, F. Wang, and B. Ge, "Characterization of toxin genes and antimicrobial susceptibility of Staphylococcus aureus isolates from Louisiana retail meats," Foodborne Pathogens Disease, vol. 8, pp. 299-306, 2013.

[44] H. H. Ali, "Isolation and identification of Staphylococcus bacteria from fish of fresh water and its antibiotics sensitivity in Mosul city," Basrah Journal of Veterinary Research, vol. 13, no. 1, pp. 33-42, 2014.

[45] L. P. de Oliveira, L. S. S. Barros, V. C. Silva, and M. G. Cirqueira, "Study of Staphylococcus aureus in raw and pasteurized milk consumed in the Reconcavo area of the State of Bahia," Food Processing \& Technology, vol. 2, no. 6, p. 128, 2011.

[46] F. Y. Chye, A. Abdullah, and M. K. Ayob, "Bacteriological quality and safety of raw milk in Malaysia," Food Microbiology, vol. 21, no. 5, pp. 535-541, 2004.

[47] K. Ekici, H. Bozkurt, and O. Isleyici, "Isolation of some pathogens from raw milk of different milch animals," Pakistan Journal of Nutrition, vol. 3, no. 3, pp. 161-162, 2014.

[48] M. N. Agban and A. S. Ahmed, "Detection and identification of Staphylococcus aureus enterotoxins in some milk products and their handlers," Egyptian Journal of Medical Microbiology, vol. 22, no. 2, pp. 101-112, 2013.

[49] H. M. Al-khafaji, "Detection of enterotoxins genes in Staphylococci isolated from milk and cheese," $\mathrm{Ph} \mathrm{D}$. Thesis, College of Science-University of Baghdad, Baghdad, Iraq, 2013.

[50] J. Y. Mustafa, "Isolation of some bacterial causative agent of bovine mastitis, with extraction and purification of Staphylococcus aureus B lactamase," M Sc. Thesis, College of Veterinary Medicine, University of Basrah, Basra, Iraq, 2007.

[51] O. Y. Y. Ahmed, N. E. Awadalla, and I. E. M. El Zubeir, "Incidence of some potential pathogens in raw milk in Khartoum North [Sudan] and their susceptibility to antimicrobial agents," Journal of Animal and Veterinary Advances, vol. 4, pp. 341-344, 2005.

[52] K. G. Abdel-hameed and L. M. El-Malt, "Public health hazard of the Staphylococcus aureus isolated from raw milk and ice cream in Qena governorate," Journal of Veterinary Medicine, vol. 55, no. 121, pp. 191-200, 2009. 
[53] M. A. Islam, M. L. Kabir, S. M. Shariful Hoque Belal, M. M. Meher, and M. T. Rahman, "Molecular detection and characterization of Staphylococcus aureus isolated from raw milk sold in different markets of Bangladesh," Journal of Veterinary Medicine, vol. 14, no. 2, pp. 277-282, 2016.

[54] M. Jahan, M. Rahman, S. Parvej et al., "Isolation and characterization of Staphylococcus aureus from raw cow milk in Bangladesh," Journal of Advanced Veterinary and Animal Reserch, vol. 2, no. 1, pp. 49-55, 2016.

[55] H. Thaker, M. Brahmbhatt, and J. Nayak, "Isolation and identification of Staphylococcus aureus from milk and milk products and their drug resistance patterns in Anand, Gujarat," Veterinary World, vol. 5, no. 12, pp. 10-13, 2013.

[56] G. F. Beyene, "Antimicrobial susceptibility of Staphylococcus aureus in cow milk, Afar Ethiopia," International Journal of Modern Chemistry and Applied Science, vol. 3, no. 1, pp. 280-283, 2016.

[57] H. Abraha, G. Hadish, B. Aligaz, G. Eyas, and K. Workelule, "Antimicrobial resistance profile of Staphylococcus aureus isolated from raw cow milk and fresh fruit juice in Mekelle, Tigray, Ethiopia," Journal of Veterinary Medicine and Animal Health, vol. 10, no. 4, pp. 106-113, 2018.

[58] H. I. Idbeis, "Detection of enterotoxin genes [sea-see] of Staphylococcus aureus isolated from raw milk by multiplex PCR and study of their pathogenicity," M.Sc. Thesis, College of Veterinary Medicine- University of Basrah [Microbiology], Basra, Iraq, 2008.

[59] H. M. AL-Marsomy, "Isolation and diagnostic some bacterial causes of mastitis in cows and role of lactobacillus secretion on inhibition growth of Staphylococcus aureus," M.Sc. Thesis, College of Veterinary Medicine, University of Baghdad, Baghdad, Iraq, 2008.

[60] A. Bendahou, M. Lebbadi, L. Ennanei, F. Z. Essadqui, and M. Abid, "Characterization of Staphylococcus species isolated from raw milk and milk products [lben and jben] in North Morocco," Journal of Infection in Developing Countries, vol. 2, no. 3, pp. 218-225, 2008.

[61] A. A. AL-Saady, Extraction and characterization of surface adherence protein from methicillin resistance Staphylococcus aureus and study of the pathogenic effects, Ph.D. Thesis, College of Science, University of Baghdad, Baghdad, Iraq, 2007.

[62] F. Peles, M. Wagner, L. Varga et al., "Characterization of Staphylococcus aureus strains isolated from bovine milk in Hungary," International Journal of Food Microbiology, vol. 118, no. 2, pp. 186-193, 2007. 